\title{
The History of the Text of Aristophanes
}

\author{
Alan H. Sommerstein
}

\section{Preliminary Remarks}

An interval of twenty-four centuries separates the scripts that Aristophanes wrote for the first performances of his comedies from the texts of those comedies as they appear, for example, in Wilson (2007b). This chapter attempts to trace the chain of transmission that leads from the former to the latter. ${ }^{1}$ The basic process in this chain is that of copying — by hand, for the first nineteen centuries, and thereafter with mechanical, and very recently with electronic, assistance. Copying, however it is performed, is always liable to error. Those who copy texts are normally aware of this, or at least are supervised by persons who are aware of it and are on the lookout for possible errors in the text they are copying. Often an error will be detected and successfully corrected, thanks either to the copyist's or editor's own understanding of language, style, and context, or to comparison with another copy that has escaped the error; but there is always also the possibility that an attempted 'correction', far from restoring the text as it was before the error appeared, may actually take it further away from that state, ${ }^{2}$ or that an 'error' may be detected where the text was in fact sound. ${ }^{3}$ When all copying is by hand, the net outcome of this process, at most times and in most circumstances, will be a slow increase in the distance between the original and the current state of the text. If this tendency has been reversed in the last half millennium, as on the whole it has, this is due partly to the technology of printing (and later developments that have built upon it), which has both vastly increased the dissemination of texts and reduced the number of separate acts of copying required to effect it, thus putting a virtual halt to the long process of random deterioration; partly (though for most texts, including Aristophanes, only to a rather small extent) to the discovery, mostly in Egypt, in and since the nineteenth century, of fragments of copies far older than any previously known; partly to improvements in communications that have made it possible, as it never was in ancient or mediaeval times, for one editor to have access to virtually all the significant evidence existing in the world that bears on the constitution of the text; and partly to the advancement of our knowledge and understanding of the transmission of texts, the ways in which errors can occur, and the forms they can take.

The above remarks apply, with minor variations, to all ancient Greek texts. I now turn to consider the text of Aristophanes in particular. 


\section{The Earliest Days}

The script of a dramatic performance is inherently unstable. Any text may be altered after its completion as a result of second thoughts by the author; but in a play text, the director, ${ }^{4}$ the performers, and the audience(s) have also to be considered. The script may be changed during the rehearsal period before the first performance, or afterwards with a view to subsequent performances. The impact of such changes on the eventual dissemination of the script as a reading text may take any of three forms.

(i) The change never finds its way at all into the copy or copies of the script from which later reading texts derive. In this case, we will never know about it for sure, except in the unlikely event that a reliable tradition about the actual performance is eventually committed to writing by a later author and either survives in that author's text or is quoted therefrom by another surviving writer.

(ii) The change is inserted by the author into his working copy. In this case, too, we will usually never know that any change was ever made, but for the converse reason that evidence of the earlier state of the text will normally not survive. Sometimes, however, for special reasons, the alteration will leave visible traces. In Wasps, one of the choral interludes (1265-1291) contains, in the mediaeval manuscripts, a strophe, epirrhema, and antepirrhema, but no lyric antistrophe. The scholia state that something is missing, but that in itself might be merely an inference based on Aristophanes' normal practice. However, the first-century metrician Heliodoros ${ }^{5}$ reports that where the antistrophe should come there were 'seven lines ${ }^{6}$ containing dots and marks indicating a corrupt text ( $\sigma \tau \imath \gamma \mu \mathrm{a} \varsigma \kappa \alpha \dot{l}$ à $\lambda o ́ \gamma o v \varsigma)$, whose sense cannot readily be established'; he assumed, as he had 'often said' in regard to other similar passages, ${ }^{7}$ that these lines were already corrupt in 'the earliest copies'- too corrupt to be intelligible to later scholars (say, in Hellenistic Alexandria). Since it is unlikely that any merely accidental process (e.g., a damp patch) would so neatly ruin an entire antistrophe while leaving the adjacent epirrhema and antepirrhema untouched, we must suspect that there has been an intentional deletion, and I have suggested (Sommerstein 1983, 233) that Aristophanes himself cut out the song before production, perhaps because someone satirised in it had suddenly died. Either this happened so late that there was no time to write substitute lyrics, or Aristophanes forgot or did not care ${ }^{8}$ to insert the substitute text in his working script after deleting the original; in either case, all that was left of the antistrophe was a half-erased passage in which, in the words of Heliodoros, it was possible 'to determine how many lines there were, but not what was in them'. A late insertion, too, may betray itself by its content 
and/or by not fitting quite perfectly into its context: an example of the former is the passage in Ecclesiazusae (1154-1162) that refers to the result of the drawing of lots for the order of performance of the competing plays, while the latter is exemplified by the passages in Frogs (71-88, 786-795, 1515-1519) that presuppose, as the rest of the play does not, the death of Sophocles. ${ }^{9}$ Other changes in Frogs appear to have been made at a later stage, for a repeat performance about a year after the first, and inserted in the working script at the top or bottom of the relevant columns, without obliterating the original text, so that we have been left with a series of doublet passages. ${ }^{10}$

(iii) If the alterations are extensive, it may become necessary to write out the script again from scratch. This is clearly what was done when Clouds was revised, some years after its first performance, and both the original and the (incompletely) revised script survived to be catalogued and discussed by ancient scholars ${ }^{11}$ (it was the revised script that made it into late antiquity and is preserved today). More surprisingly, it also seems to have happened when some apparently rather minor revisions ${ }^{12}$ were made to Wealth for a second production on an unknown occasion; here again the original and revised versions both survived to be studied by at least one later scholar, leading him to the absurd conclusion that the earlier version (the one we have now) was actually the play of the same name that Aristophanes had presented twenty years earlier-in spite of ample internal evidence that it belonged to the period of the Corinthian War. ${ }^{13}$ In a case like this, the 'rewriting' may have been merely a matter of cutting and pasting (in the literal, not the computer-age, sense) the particular columns of text in which alterations had been made.

These various phenomena, especially the apparent deletion in Wasps and the doublets in Frogs, strongly suggest that our texts of the plays derive ultimately from what I have called Aristophanes' 'working scripts', which were first written out in fair copy (presumably before rehearsals began) and updated as necessary — and sometimes rewritten - to take account of subsequent changes. We may note, too, that if a text was rewritten, both the earlier and the later versions of it might sometimes go into circulation. ${ }^{14}$ But that statement raises another question: how did copies of these 'working scripts' get into circulation, for some of them eventually to find their way, a century after the author's death, into the catalogue of the Library of Alexandria?

\section{The Fourth Century}

Aristophanes' literary heirs will certainly have been his sons, Philippos and Araros ${ }^{15}$ —both of whom, like so many sons and other relatives of great Athenian dramatists, followed him 
into the same profession. Philippos, who was given his paternal grandfather's name, was presumably the elder, but their father evidently thought Araros the more talented ${ }^{16}$ and entrusted to him the production of the last two plays he wrote. ${ }^{17} \mathrm{We}$ are told, however, that Araros did not produce any of his own plays at Athens until some time in the 101st Olympiad (i.e., between 375 and 372 , inclusive) $;^{18}$ I suspect that for a considerable part of the intervening period, he may have been making a good living by producing his father's comedies in other parts of the Greek world, especially in the west. ${ }^{19}$ Philippos meanwhile remained at home, looking after the family property and from time to time composing comedies himself (he won first prize at the Lenaia at a date not later, and probably a little earlier, than 378). ${ }^{20}$ Araros will of course have taken copies of his father's scripts with him on his travels, but it would make sense for Philippos to retain the originals at Athens and make them available for copying, whether as a free service to friends or as a paid one to booksellers. There had been a regular book trade at Athens, with stalls concentrated in a particular section of the agora, at least since the late fifth century, ${ }^{21}$ and Old Comedy, despite its focus on issues and personalities topical at the time of production, was evidently succeeding in retaining ${ }^{22}$ a reading public even though, at Athens at least, it no longer had a spectating public. By the third quarter of the fourth century, when Aristophanes' plays can hardly have been seen on the Athenian stage for fifty years, and when a completely different kind of comedy was the current fashion, it was possible for Aristotle (Poetics 1448a25-28) to assume that his students would have a general familiarity with the nature of Aristophanic comedy and for one contemporary dramatist, Timokles, to compose comedies that seem to have reproduced some of its main characteristics and captured some of its spirit with a considerable measure of success: both of them can have known Aristophanes only from written texts. No attempt was made at this time to designate an official text-as was done on the initiative of Lykourgos for Aeschylus, Sophocles, and Euripides ${ }^{23}$ — since the motive for doing so (to regulate performances) was absent in the case of Old Comedy. However, the absence of performances also removed what in the fourth century was the main danger to the integrity of dramatic texts: the eternal yearning of producers and actors to 'improve' upon them, which led to so many interpolations in the texts of tragedy. ${ }^{24}$ The texts were subject only to the ordinary vicissitudes of uncontrolled copying, and these had not had time to do vast damage before the texts came for the first time into the hands of a community of scholars.

At this time the texts of Aristophanes will have been far from reader friendly. Quite apart from the absence of explanatory comment — which will have made many parts of the 
plays increasingly hard to understand a century or so after their original production - and the absence of spaces or other indications of word division (a feature then common to virtually all written texts, and one therefore with which readers must have learned by experience to cope), a crucial problem would have been the lack of reliable indications of the identity of speakers and the points at which there was change of speaker. Early papyri almost never give the names of speakers; they usually indicate change of speaker by a horizontal stroke ( $\left.\pi \alpha \rho \alpha ́ \gamma \rho \alpha \varphi)_{)}\right)$under the line in which a speech ends and (if the change was in the middle of a line) by means of a dicolon (:) or a small blank space. ${ }^{25}$ This system was doubtless devised in the first place for tragedy, in which it was reasonably satisfactory: in tragedy it was rare for a line to be broken between two speakers, and even rarer for a speech to begin in the middle of one line and continue into the next. In comedy (of all periods) speeches might begin and end at almost any point of a line, and a line might be divided into three, four, or even more little speeches or parts of speeches $;^{26}$ the number of dramatis personae, too, could be very large, ${ }^{27}$ and four of them might be on stage at once. ${ }^{28}$ Before the age of Alexandrian scholarship, perhaps only other comic dramatists would be able to read an Aristophanic text with much fluency.

\section{Hellenistic Scholarship ${ }^{29}$}

The library founded at Alexandria by Ptolemy I soon acquired what became by far the greatest collection of poetic and prose texts that had ever been assembled under one roof. Its directors and their royal patrons seem to have done all they could to make these collections complete, especially as regards poetry, but this could never be more than an ideal aim: thus in the genre of comedy, there were many plays known to have been produced of which no text could be found, including some by major authors ${ }^{30}$ - and there were at least some plays of which texts existed elsewhere but not at Alexandria. ${ }^{31}$ Of Aristophanes, already regarded as the outstanding and typical representative of Old Comedy, it seems likely that very little was missed; apart from Peace II (see note 31), there is only one, doubtful reference to an Aristophanic play from which no quoted fragments survive. ${ }^{32}$

Aristophanes was extensively studied by third-century scholars such as Lykophron, ${ }^{33}$ Kallimachos, ${ }^{34}$ and Eratosthenes, ${ }^{35}$ but they did not concern themselves systematically with the constitution of his text. ${ }^{36}$ This had to wait for the early second century and the poet's namesake, Aristophanes of Byzantion ('Ar. Byz.'), who constituted a critical text on the basis of the manuscript evidence available to him, ${ }^{37}$ marking problematic passages with marginal signs as was done in critical texts of the Homeric poems $;{ }^{38}$ he was probably also the first to 
insert accents and breathings systematically ${ }^{39}$ and the first to divide the lyrics into cola ${ }^{40}$ (previously they had been written continuously like prose), and he certainly wrote introductory notes, which formed the nuclei of the hypotheses prefixed to the text of the plays in mediaeval manuscripts. ${ }^{41}$ His text appears to have been, at the very least, extremely influential in the subsequent history of the textual tradition. ${ }^{42}$

None of these scholars seems likely to have composed a continuous commentary $(\mathrm{u}(\mathrm{po} / \mathrm{mnhma})$ on Aristophanes - a book of explanatory notes, each keyed to a word or phrase of the poet's text. This was first done, in the generation after Ar. Byz., by Euphronios $^{43}$, Kallistratos, and above all Aristarchos. Euphronios is never cited in the scholia on textual matters; Kallistratos is occasionally, though it is not clear that he ever departed from the readings favoured by his teacher Ar. Byz. ${ }^{44}$ Aristarchos, as one might expect in the light of his work on Homer, takes considerable interest in textual questions, discussing readings, accentuation, speaker assignments, and the authenticity of lines. ${ }^{45}$ The work of these and other commentators ${ }^{46}$ was consolidated, in the time of Caesar, Antony, and Augustus, by the hyperproductive Didymos-whose variorum commentary, ${ }^{47}$ which incorporated many ideas of his own (of widely varying quality ${ }^{48}$ ), appears to be, through a later compilation by one Symmachos, ${ }^{49}$ the ultimate source of the scholia in the mediaeval

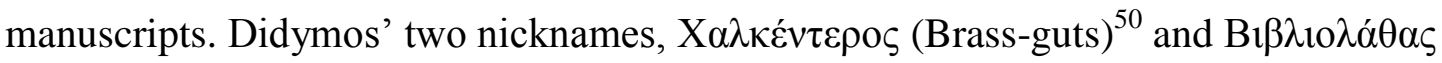
(Forgets-what-he-wrote), ${ }^{51}$ testify respectively to his indefatigability and his carelessness; his work has been characterised, on the basis of the only extensive surviving specimen (a papyrus fragment of a commentary on Demosthenes) as 'potted scholarship, hurried compilation rather than intelligent re-interpretation'. ${ }^{52}$ Without it, however, there is little doubt that we would have been deprived of most of the fruits of three centuries of Aristophanic exegesis.

\section{Papyri $^{53}$}

The history of reader interest in Old Comedy in antiquity, as it appears from the surviving papyri, can be divided into two phases, with the break coming around $300 \mathrm{CE}{ }^{54}$

In the earlier phase, it is clear that the big three of Old Comedy-Eupolis atque $\underline{\text { Cratinus Aristophanesque poetae }}^{55}$ - all continued to be fairly widely read. From this period we have sixteen fragments from the eleven surviving plays of Aristophanes ${ }^{56}$ seven others that can be fairly confidently associated with him, ${ }^{57}$ six that are attributable to Eupolis, two to Kratinos, and seventeen more whose authorship cannot be determined. ${ }^{58}$ After 300 CE the pattern changes completely. From the next three centuries, there survive thirty-two papyri 
containing the text of, or scholia on, one or more of the eleven extant plays of Aristophanes, ${ }^{59}$ and only four from all the rest of Old Comedy_one that may come from a lost play of Aristophanes, ${ }^{60}$ one from Eupolis, ${ }^{61}$ and two or three anonymous fragments. ${ }^{62}$ From this time on, it is clear, Old Comedy in effect meant Aristophanes, and Aristophanes meant the eleven plays that we now possess.

The third and fourth centuries were the period during which the codex - the book as we know it, consisting of leaves (usually then of parchment) laid one on top of the other with their edges bound together-came to replace the papyrus roll as the normal vehicle for long texts; the change has been described as 'the first major bottle-neck through which classical literature had to pass'. ${ }^{63}$ Menander negotiated the bottleneck with ease; for Old Comedy it will have been more difficult. Plutarch had already complained two centuries earlier that it was impossible to read Old Comedy without a commentary $;{ }^{64}$ now, therefore, it would have been generally felt that Old Comic texts were not worth copying into the new format unless their commentaries were copied too. It may well be that it was at just about this time that the eleven plays that were to survive were equipped with a new commentary, incorporating the work of earlier commentators but in some respects more elementary; ${ }^{65}$ probably Aristophanes had already established the place in the school curriculum that he was to retain with ease, Christianity notwithstanding, throughout the Byzantine era ${ }^{66}$. Simultaneously with the change of format, the practice also began of writing annotations (called scholia) in the margins of the codex pages ${ }^{67}$ - though it was a long time before it became common to house an entire commentary in these margins, and in the fifth century, separate commentary books were still being written. ${ }^{68}$

The papyri present, in general, a text not very different from that which underlies the mediaeval tradition, and their contribution to the solution of Aristophanic textual problems, though far from negligible, is not very great. ${ }^{69}$

\section{The Early Mediaeval Tradition}

During the eighth century, when learning (in everything except theology) in the Byzantine Empire was at a low ebb, the preservation of classical poetry can have been assured only by the dull, unthinking conservatism of the schools. When interest in pagan antiquity revived among the elite in the ninth century - a revival associated above all with the name of Photios, patriarch of Constantinople (858-867 and 877-886) ${ }^{70}$ - texts of Menander were no longer to be found. Those of Aristophanes were soon, like others, transcribed into the new, smaller 'minuscule' script (the direct ancestor of the lowercase Greek scripts and fonts used today) in 
codices in which the scholia might occupy as much or more space than the text. We cannot be sure, and it does not much matter to our understanding of the history of the text, whether this transcription was done only once or more than once. What does matter is that there are many passages in which more than one reading came down from late antiquity into the mediaeval tradition $^{71}$ and that some such ancient readings may now be known to us only from manuscripts of the late thirteenth or fourteenth century. ${ }^{72}$ They may have (re)entered the tradition from marginal variants, from scholia, or from late antique manuscripts that were collated but not transcribed (perhaps being discovered in out-of-the-way libraries long after the main transcriptions had been made) — or there may, in some plays (or parts of plays), have been more than one full transcription made.

The mediaeval tradition of Aristophanes, like the ancient one, can be divided into two phases, but in this case the division is clearly marked by two political watersheds: the sack of Constantinople by the army of the Fourth Crusade in 1204, and the reestablishment of the Greek Empire there by Michael VIII Palaiologos in 1261. From the earlier phase, there survive at most five manuscripts and one commentary; from the later, more than 170 manuscripts ${ }^{73}$ and much scholarly work. Almost from the start, three of the eleven plays-

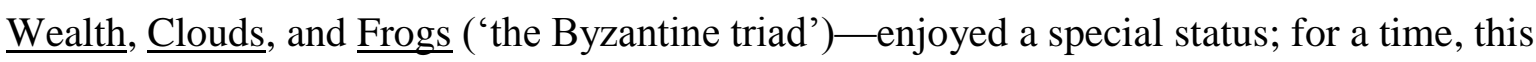
may have been partly shared by Birds,${ }^{74}$ but already by the late twelfth century, Birds had dropped out of the inner canon. Thus, whereas some 90 percent of the surviving manuscripts contain $\underline{\text { Wealth}}$, and there are also a very large number containing $\underline{\text { Clouds }}(139)^{75}$ and Frogs (about ninety), no other play is preserved in more than thirty (nights), and the text of one play, and substantial parts of another, depend on a single manuscript. ${ }^{76}$

The oldest of the mediaeval manuscripts, and the only one containing all eleven plays, is Ravennas 429 (R), of the mid-tenth century. ${ }^{77} \mathrm{R}$ 's text is copied fairly mechanically and contains many errors, but few attempted corrections; it certainly, overall, contributes more to the establishment of the text than any other single manuscript, but its relative value varies very much from play to play and is never overwhelming (except, of course, where no other independent witness survives). The scholia appear in $\mathrm{R}$ in a very abbreviated form.

Probably a little younger than $\mathrm{R}$ is a palimpsest in Florence (Laurentianus LX 9), ${ }^{78}$ on which can be read about sixty lines of Birds (1393-1454); this seems, both in its text and in its scholia, to be an early representative of a branch of the tradition not otherwise attested (outside the triad) before Palaiologan times. ${ }^{79}$

The next oldest manuscript, and (until we get to the late fourteenth century) the next most extensive after R, is Venetus Marcianus 474 (V), now regarded as belonging to the late 
eleventh century $;^{80}$ it contains the Byzantine triad followed by Knights, Birds, Peace, and Wasps. The copyist of V, or of an ancestor of V, appears to have been more attentive and skilful in the matter of noting, and accepting or rejecting, marginal variants than was the case with $\mathrm{R}$, and in some parts of the corpus, especially in Wasps, V preserves the truth alone with remarkable frequency. The scholia in $\mathrm{V}$ are much fuller and more reliable than those in $\mathrm{R}$.

Two other manuscripts are likely to belong to the late twelfth century. Ambrosianus C 222 inf. (K), ${ }^{81}$ in Milan, contains the whole of the triad; its quality was recognised, particularly by Dover $(1968,1993)$, long before it was shown by Mazzucchi $(2003,2004)$ to have been written in the 1180s - it is the earliest witness to the commentary of Tzetzes (see below), and the only manuscript to preserve the notation $\chi$ opoũ at Wealth 1096/7. ${ }^{82}$ The date of Matritensis 4683 (Md1) ${ }^{83}$ has long been disputed, but the hand of the older portion ${ }^{84}$ is hard to date later than the twelfth century. ${ }^{85}$

The twelfth-century scholar John Tzetzes (ca. 1110-1180), ${ }^{86}$ by adapting earlier scholiastic material and adding much of his own, created a complete commentary on the triad and a sketchier one on Birds; his work is preserved in $\mathrm{K}$ and in the fourteenth-century manuscript Vaticanus Urbinas 141 (U). He certainly had access to a significant amount of ancient material now lost, and this seems to have included at least one source of good Aristophanic readings of which we would not otherwise have known. ${ }^{87}$

In the Palaiologan period (1261-1453), we meet for the first time a scholar, Demetrios Triklinios (ca. 1280-after 1332), ${ }^{88}$ who not only systematically edited the texts of whole plays as no one had done since Alexandrian times, but also, just as systematically, altered them where he thought sense or metre were defective. For this very reason, the key witnesses to the text from this period are those whose text does not show signs of his intervention. Outside the Byzantine triad, ${ }^{89}$ the most important of these are the following: ${ }^{90}$

(1) Parisinus Regius gr. 2712 (A), containing the triad together with Knights, Birds, $\underline{\text { Acharnians, }}$, and the beginning of Ekklesiazousai $;{ }^{91}$ it has practically no scholia.

(2) Estensis gr. 127 (E), in Modena, containing the triad plus Knights, $\underline{\text { Birds }},{ }^{92}$ and Acharnians, with very full scholia. This manuscript was in the possession of Marcus Musurus, editor of the Aldine edition (see below); he made extensive use of it for the scholia, but underrated its value for the text.

(3) Ambrosianus L39 sup. (M), in Milan, containing the triad, Knights, and most of Birds.

(4) Vaticanus Urbinas $141(\mathrm{U})$, containing the triad and Birds, with scholia based on the commentary of Tzetzes (see above). 
(5) Laurentianus XXXI 15 + Vossianus gr. F 52 (Г), now in two parts, in Florence and Leiden, respectively. This manuscript is unusual in not containing the Byzantine triad; it covers seven of the other eight plays (missing only Thesmophoriazousai), but in most of them, it has large gaps (some of which it took over from a defective exemplar, ${ }^{93}$ while others are due to damage suffered by $\Gamma$ itself). Several hands have added corrections and variants (some of great importance) and extra scholia.

(6) Laurentianus conventi soppressi $140(\Theta)$, in Florence, containing the triad and Knights.

These six manuscripts, together with $\mathrm{R}$ and $\mathrm{V}$, provide complete coverage of the preTriklinian textual tradition in Knights, Birds, and Acharnians. In Wasps, Peace, $\underline{\text { Lysistrata, }}$ and most of Ekklesiazousai, however, we have only R, V (in Wasps and Peace), and $\Gamma$ (when available), and editors therefore find it necessary to cite some later manuscripts regularly, particularly the following:

(7) Vaticanus Palatinus gr. $128(\mathrm{Vp} 3),{ }^{94}$ of the fifteenth century ( $\underline{\text { Knights, }}$ Acharnians, Wasps).

(8) Vaticanus Palatinus gr. $67(\mathrm{Vp} 2),{ }^{95}$ of the fifteenth century (the same three plays, plus the triad, $\underline{\text { Birds }}, \underline{\text { Peace, }}$, and most of Lysistrata). In most of the plays it contains, Vp2 has a post-Triklinian text, but in Peace, it is pre-Triklinian, and Lysistrata seems never to have been edited by Triklinios at all.

(9) Hauniensis $1980(\mathrm{H})$, in Copenhagen, of the fifteenth century - a twin of Vp2.

(10) Parisinus Regius 2717 (C), of the sixteenth century; this very carelessly written manuscript contains the same plays as $\mathrm{Vp} 2$ and $\mathrm{H}$, and it is very close to them in $\underline{\text { Birds, }} \underline{\text { Peace, }}$ and Lysistrata, but in $\underline{\text { Acharnians }}$ and $\underline{\text { Wasps }}$, it is a twin of Vp3. ${ }^{96}$

(11) Perusinus H56 ( $\Lambda),{ }^{97}$ in Perugia, of the fifteenth century; it contains only

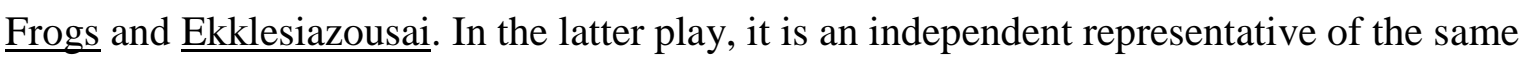
family as $\mathrm{A}$ and $\Gamma$, and (together with its copy, $\mathrm{Mu} 1^{98}$ ) it is the only manuscript other than $\mathrm{R}$ to preserve the ending of the play (from line 1136).

There can be no overall stemma codicum for the text of Aristophanes. In the Byzantine triad, the abundance of available copies, and therefore of opportunities for collation and correction, was always so great that their tradition has to be treated as an 'open recension'; ${ }^{99}$ outside the triad, the affinities of manuscripts frequently change from one play to another, and sometimes within a play, ${ }^{100}$ so that the tradition of each play has to be analysed separately. ${ }^{101}$ 
Two great scholars living close to the end of the thirteenth century, Maximos Planudes and Manuel Moschopoulos, are known to have commented on the triadic plays, but neither of them seems to have written a full commentary ${ }^{102}$ and neither can be conclusively proved to have made any emendations in the text. ${ }^{103}$ An important figure of the next generation, Thomas Magistros (ca. 1275-1350), did produce a full commentary, much of which was taken over by his pupil Triklinios. He is sometimes said, or assumed, to have prepared a recension of the text, ${ }^{104}$ but the evidence does not provide clear justification for such a claim. ${ }^{105}$

Triklinios' own editorial work can be followed in some detail, at least for the triad, thanks to the survival of Parisinus suppl. gr. 463 (P20), ${ }^{106}$ which contains his corrections and scholia; copies of it were made at various times, and these (or their surviving descendants) accordingly reflect the different stages of his editorial activity. Eventually, Triklinios must have given up using P20 as his working copy and prepared another, which he extended to cover a total of eight plays (the triad plus $\underline{\text { Knights, }} \underline{\text { Acharnians, }} \underline{\text { Wasps }}, \underline{\text { Birds }}$, and Peace); from this is descended Holkhamensis 88 (L), now in Oxford, written in the early fifteenth century, which gives us what (so far as we can tell) is Triklinios' final recension of the Aristophanic text. ${ }^{107}$

Triklinios' understanding of classical metre far exceeded that of any mediaeval predecessor. Thanks to his study of the metrical scholia and of Hephaestion's handbook on metre, he had a good grasp of the simpler verse patterns, and while there was much about lyrics that he never came to understand, ${ }^{108}$ he did know about strophic responsion. This knowledge he put to work in emending his texts. Often his intervention proves to be for the worse: his feeling for style and his understanding of the principles of word order and the use of particles were far inferior to his metrical knowledge, and sometimes-for example through taking a long vowel to be short or vice versa- he may 'correct' a text that is in fact perfectly sound. But there is much that he was able to put right, and in Wasps alone he has restored the true reading, in my judgement, in some twenty places. His recension exercised an enormous influence on the subsequent manuscript tradition ${ }^{109}$ and, working through the Aldine edition (see below), on the first three centuries of the printed tradition also.

In the fifteenth century we find a scattering of other successful emendations (and, as always, a larger number of unsuccessful ones) here and there in manuscripts of the triadic plays, many of them by now written by refugee scholars (or their local pupils) in Italy. One other manuscript of this period deserves special mention. Parisinus Regius 2715 (B) is based partly on a Triklinian manuscript close to (but not identical with) L, partly on $\Gamma$ (or more 
likely a copy of $\Gamma),{ }^{110}$ from which it acquired most of Lysistrata and Ekklesiazousai $;{ }^{111}$ like $\Gamma$, it omits the triadic plays. Its distinctive feature, however, is the presence of many new emendations, a considerable number of which (at least a dozen in Wasps, for example) have rightly won general acceptance; ${ }^{112}$ the quality of some of these is fully worthy of the great philologists of the sixteenth century — but their author lived long before that. As Wilson has discovered (Wilson 2007c, 12-13), the scribe of B was the wandering scholar Andronikos Kallistos (born ca. 1400, probably in Constantinople; died after 1476, in London). ${ }^{113}$ With him, we end our survey of the manuscript tradition.

An important element in the textual tradition that should not be forgotten is furnished by the many citations from the comedies, sometimes of considerable length, in the works of other ancient and mediaeval authors and in lexica, collections of proverbs, and the like; sometimes one or more of these so-called testimonia preserve a true reading that has been corrupted in all Aristophanic manuscripts. ${ }^{114}$ By far the most extensive source of testimonia is the tenth-century lexicon/encyclopaedia known as the $\underline{\text { Suda, }}$, which cites, for example, nearly two hundred lines of Wasps; it exhibits a text that is often close to that of its near contemporary R.

\section{The First Printed Editions}

The first printed edition of Aristophanes, as of so many ancient authors, was published by Aldus Manutius ${ }^{115}$ at Venice in 1498. It was edited by the Cretan Marcus Musurus and contained nine plays; originally he had expected to include only seven, but Peace and Ekklesiazousai were added before publication. His main copy text, as has long been recognised, must have been a Triklinian manuscript, and a fragment of it (containing only

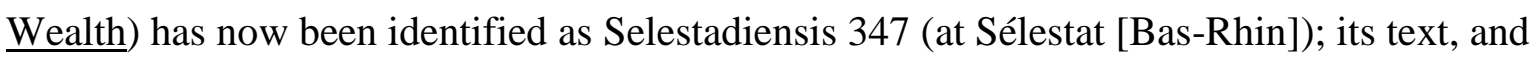
that of the Aldine so far as it is dependent thereon, is closely akin to that of L, though not, as the manuscript's discoverer thought, actually derived from L. ${ }^{116}$ Musurus also had E in his possession ${ }^{117}$ and from it derived corrections and most of his scholia on those plays it contained; and his last-minute addition of Peace and Ekklesiazousai shows that he later acquired a third manuscript, which must have contained the end of Peace intact (like R, Vp2, $\mathrm{H}$, and $\mathrm{C}$ ) and the whole of Ekklesiazousai (like $\mathrm{R}$ and $\Lambda$ ) — the manuscript certainly was not $\mathrm{R}$, so it is likely to have been a manuscript related to $\mathrm{Vp} 2, \mathrm{H}$, and $\mathrm{C}^{118}$ that had picked up a complete text of Ekklesiazousai from a twin of $\Lambda .{ }^{119}$ Lysistrata and Thesmophoriazousai were first printed at Florence in 1516 as a supplementary volume to the 'Juntine' edition, the editor being Euphrosynus Boninus. Boninus' copy text was none other than R; the subsequent 
history of the text of Aristophanes would have been very different if he had discovered $\mathrm{R}$ in time to be able to use it for the other nine plays, or if he had thought of re-editing them with the aid of this 'antiquissimum Aristophanis exemplar' (as his publisher calls it), or if he had deposited it in a library heavily frequented by scholars.

\section{The Last Half Millennium}

The comedies were several times republished in the sixteenth and early seventeenth centuries; at this time proposals for improving the text often originated in the marginal notes of scholarly readers, and it could be a matter of luck whether they were taken up by an editor or passed into oblivion. ${ }^{120}$ The edition of L. Küster (Amsterdam, 1710) marked a considerable step forward, largely thanks to the suggestions communicated to him by Richard Bentley; so did those of R. P. F. Brunck (Strasbourg, 1783), the first editor to make systematic use of manuscript evidence (though he put too much trust in the often specious plausibility of B), and of Ph. Invernizi (Leipzig, 1794), the first since Boninus to make use of R. In the nineteenth century the broad shape of the manuscript tradition gradually came to be understood and the special position of $\mathrm{R}$ and $\mathrm{V}$ appreciated; particularly significant were the editions of Knights, Thesmophoriazousai, Frogs, Ekklesiazousai, and Wealth by A. von Velsen (Leipzig, 1869-1883), the first to be based on accurate collations of the principal manuscripts. At the same time, the text benefited at least as much from the clear identification of many corrupt passages and their judicious emendation (accompanied, as ever, by much that was far from judicious). The studies of the last hundred years have perhaps done even more to deepen and refine our knowledge of the evidence for the text, though improvement in the state of the text itself has inevitably been slower; landmarks have been the great Groningen edition of the scholia (begun by W. J. W. Koster in 1960, and completed in 2007) and the Clarendon (Oxford) series of editions of individual plays, especially those by Sir Kenneth Dover (louds, 1968; Frogs, 1993), by Nan Dunbar (Birds, 1995), and by Douglas Olson alone (Peace, 1998; Acharnians, 2002) and in partnership with Colin Austin (Thesmophoriazousai, 2004).

I can fittingly end this chapter by expressing my gratitude to Nigel Wilson for making available to me in advance of publication the introduction to his book Aristophanea (Wilson 2007c), which has been of the greatest assistance in enhancing the accuracy and up-todateness of this chapter - and also, as all Aristophanic scholars now must, for providing us at long last with a compact, reliable, and properly evidenced critical edition (Wilson 2007b) of the eleven comedies. 


\section{Bibliography}

Austin C. (1987) 'Textual problems in Ar. Thesm.', Dodoni 16, 61-92

Austin C. and Olson S.D. (2004) Aristophanes: Thesmophoriazusae (Oxford)

Barrenechea F. (2006) ‘A fragment of Old Comedy', ZPE 158, 49-54

Bastianini G. et al. (2006) Commentaria et lexica graeca in papyris reperta (CLGP) Pars I, Vol. 1, Fasc. 4 (Aristophanes-Bacchylides) (Munich)

Boudreaux P. (1919) Le texte d'Aristophane et ses commentateurs (Paris)

Cammelli G. (1942) ‘Andronico Callisto’, La Rinascita 5, 104-121 and 174-214

Carey C. (2007) Lysiae orationes cum fragmentis (Oxford)

Casanova A. (2000) 'La revisione delle Nuvole di Aristofane', Prometheus 26, 19-34

Csapo E.G. (1993) 'Deep ambivalence: notes on a Greek cockfight', Phoenix 47, 1-28 and $115-124$

Dawe R.D. (1967) 'The end of Seven against Thebes', CQ 17, 16-28

Dawe R.D. (1978) 'The end of Seven against Thebes yet again', in R.D. Dawe et al. ed. Dionysiaca: nine studies in Greek poetry by former pupils, presented to Sir Denys Page (Cambridge) 87-103

Dickey E. (2007) Ancient Greek scholarship: a guide to finding, reading, and understanding scholia, commentaries, lexica, and grammatical treatises, from their beginnings to the Byzantine period (New York)

Diller A. (1974) 'The age of some Greek classical manuscripts', in J.L. Heller ed. Serta Turyniana: studies in Greek literature and palaeography in honor of Alexander Turyn (Urbana) 514-524

Donadi F. (1976) 'Esplorazioni alla tradizione manoscritta dell'Encomio di Elena gorgiano', BIFG (Padua) 3, 225-250

Dover K.J. (1968) Aristophanes: Clouds (Oxford)

Dover K.J. (1988) 'Explorations in the history of the text of Aristophanes', in The Greeks and their legacy. Collected papers, II: prose literature, history, society, transmission, influence (Oxford) 223-265

Dover K.J. (1993) Aristophanes: Frogs (Oxford)

Dunbar N.V. (1995) Aristophanes: Birds (Oxford)

Eberline C.N. (1980) Studies in the manuscript tradition of the Ranae of Aristophanes (Meisenheim am Glan) 
Finglass P.J. (2009) 'Unpublished conjectures at Leiden on the Greek dramatists', GRBS 49, $187-221$

Förstel C. and Rashed M. (2003) 'Ein neues Aristophanes-Fragment (Ekkl. 283-444) aus Paris', $M H$ 60, 146-151

Harding P. (2006) Didymos on Demosthenes (Oxford)

Harris E.M. (1989) 'More chalcenteric negligence', CP 84, 36-44

Henderson J.J. (1987) Aristophanes: Lysistrata (Oxford)

Henderson J.J. (1993) 'Problems in Greek literary history: the case of Aristophanes' Clouds', in R.M. Rosen and J. Farrell ed. Nomodeiktes: Greek studies in honor of Martin Ostwald (Ann Arbor) 591-601

Holwerda D. (1964) 'De Heliodori commentario metrico in Aristophanem', Mnemosyne 17, 113-139

Holwerda D. (1967) 'De Heliodori commentario metrico in Aristophanem, II', Mnemosyne $20,247-272$

Kassel R. (1977) 'Aus der Arbeit an den Poetae Comici Graeci’, ZPE 25, 54-94

Kassel R. (1978) 'Aus der Arbeit an den Poetae Comici Graeci', ZPE 32, 23-33

Kassel R. and Austin C. (1983- ), Poetae comici Graeci (Berlin)

Kopff E.C. (1990) 'The date of Aristophanes, Nubes II', AJP 111, 318-329

Koster W.J.W. (1957) Autour d'un manuscrit d'Aristophane écrit par Démétrius Triclinius (Groningen)

Koster W.J.W. (1974) Scholia in Aristophanem I.3.2: scholia recentiora in Nubes (Groningen)

Kovacs D. (2003) 'Toward a reconstruction of Iphigenia Aulidensis' JHS 123, 77-103

Kovacs D. (2005) 'Text and transmission', in J. Gregory (ed.) A companion to Greek tragedy (Oxford) 379-393

Kraus W. (1931) Testimonia Aristophanea cum scholiorum lectionibus (Vienna)

Lowe J.C.B. (1962) 'The manuscript evidence for changes of speaker in Aristophanes', BICS $9,27-42$

Lowry M.J.C. (1979) The world of Aldus Manutius: business and scholarship in Renaissance Venice (Oxford)

MacDowell D.M. (1971) Aristophanes: Wasps (Oxford)

MacDowell D.M. (1994) 'The number of speaking actors in Old Comedy', CQ 44, 325-335

MacDowell D.M. (1995) Aristophanes and Athens: an introduction to the plays (Oxford) 
Massa Positano L. [with W.J.W. Koster and D. Holwerda] (1960) Scholia in Aristophanem IV.1. Jo. Tzetzae commentarii in Aristophanem: prolegomena et commentarius in Plutum (Groningen)

Mazzucchi C.M. (2003) 'Ambrosianus C222 inf. (Graecus 886): il codice e il suo autore. Prima parte: il codice', Aevum 77, 263-275

Mazzucchi C.M. (2004) 'Ambrosianus C222 inf. (Graecus 886): il codice e il suo autore. Seconda parte', Aevum 78, 411-440

Montana F. (2005) 'L'esegesi ad Aristofane su papiro', in F. Montana ed. Interpretazioni antiche di Aristofane (La Spezia) 1-53

Muzzolon M.S. (2005) 'Aristarco negli scolii ad Aristofane', in F. Montana ed. Interpretazioni antiche di Aristofane (La Spezia) 55-109

Olson S.D. (1998) Aristophanes: Peace (Oxford)

Olson S.D. (2002) Aristophanes: Acharnians (Oxford)

Page D.L. (1934) Actors' interpolations in Greek tragedy (Oxford)

Pfeiffer R.H. (1968) History of classical scholarship: from the beginnings to the end of the Hellenistic age (Oxford)

Platnauer M. (1964) Aristophanes: Peace (Oxford)

Regtuit R.F. (2007) Scholia in Aristophanem, Pars 3, Fasc. 2/3: Scholia in Aristophanis Thesmophoriazusas et Ecclesiazusas (Groningen)

Revermann M. (2006) Comic business: theatricality, dramatic technique, and performance contexts of Aristophanic comedy (Oxford)

Reynolds L.D. and Wilson N.G. (1991) Scribes and scholars: a guide to the transmission of Greek and Latin literature, 3rd ed. (Oxford)

Rogers B.B. (1907) The Plutus of Aristophanes, to which is added ... a translation of the Menaechmi of Plautus (London)

Schreiber F. (1975) 'Unpublished Renaissance emendations of Aristophanes', TAPA 105, 313-332

Sicherl M. (1979) 'Die Editio princeps des Aristophanes', in B. Haller ed. Erlesenes aus der Welt des Buches (Wiesbaden) 189-231

Sicherl M. (1997) Griechischen Erstausgaben des Aldus Manutius (Paderborn)

Sommerstein A.H. (1980) Aristophanes: Acharnians (Warminster)

Sommerstein A.H. (1983) Aristophanes: Wasps (Warminster)

Sommerstein A.H. (1985) Aristophanes: Peace (Warminster)

Sommerstein A.H. (1987) Aristophanes: Birds (Warminster) 
Sommerstein A.H. (1996) Aristophanes: Frogs (Warminster)

Sommerstein A.H. (1997) 'The silence of Strepsiades and the agon of the first Clouds', in P.

Thiercy and M. Menu ed. Aristophane: la langue, la scène, la cité (Bari) 269-282

Sommerstein A.H. (1998) Aristophanes: Ecclesiazusae (Warminster)

Sommerstein A.H. (2001) Aristophanes: Wealth (Warminster)

Sosower M.L. (1987) Palatinus Graecus 88 and the manuscript tradition of Lysias (Amsterdam)

Storey I.C. (1993) 'The date of Aristophanes' Clouds II and Eupolis' Baptai: a reply to E.C. Kopff', AJP 114, 71-84

Taplin O.P. (1977) The stagecraft of Aeschylus: the dramatic use of exits and entrances in Greek tragedy (Oxford)

Taplin O.P. (1993) Comic angels and other approaches to Greek drama through vasepaintings (Oxford)

Tarrant H. (1991) 'Clouds I: steps towards reconstruction', Arctos 25, 157-181

Trojahn S. (2002) Die auf Papyri erhaltenen Kommentare zur Alten Komödie (Munich)

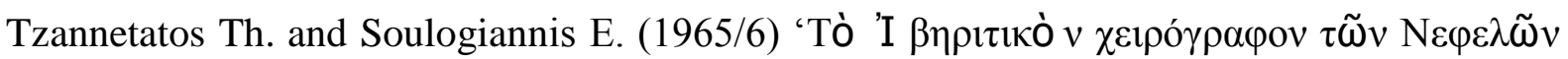

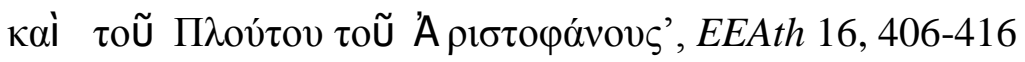

Ussher R.G. (1973) Aristophanes: Ecclesiazusae (Oxford)

Vetta M. (1989) (with D. Del Corno) Aristofane: Le donne all'assemblea (Milan)

West M.L. (1973) Textual criticism and editorial technique (Stuttgart)

West S.R. (1970) 'Chalcenteric negligence', CQ 20, 288-296

White J.W. (1906) 'The manuscripts of Aristophanes', CP 1, 1-20 and 255-278

Wilamowitz-Moellendorff U. von (1921) Griechische Verskunst (Berlin)

Wilhelm A. (1906) Urkunden dramatischer Aufführungen in Athen (Vienna)

Willi A. (2002) 'Aischylos als Kriegsprofiteur', Hermes 130, 13-27

Willi A. (2003) 'New language for a new comedy: a linguistic approach to Aristophanes' Plutus', PCPS 49, 40-73

Wilson N.G. (1962) ‘The Triclinian edition of Aristophanes', $C Q$ 12, 32-47

Wilson N.G. (1977) 'Scholarly hands of the Middle Byzantine period', in La paléographie grecque et byzantine (Paris) 221-239

Wilson N.G. (1983) Scholars of Byzantium (London)

Wilson N.G. (1992) From Byzantium to Italy (London)

Wilson N.G. (2007a) 'Scholiasts and commentators', GRBS 47, 39-70

Wilson N.G. (2007b) Aristophanis fabulae (Oxford) 
Wilson N.G. (2007c) Aristophanea: studies on the text of Aristophanes (Oxford)

\footnotetext{
${ }^{1}$ Readers new to the study of the history and criticism of texts are urged to consult West (1973) and Reynolds and Wilson (1991). Kovacs (2005) provides an excellent brief account of the transmission of tragic texts, though that of comic texts is not in all respects parallel.

${ }^{2}$ Textual critics often refer to this phenomenon by the expressive German term Verschlimmbesserung, roughly translatable as 'im-worsen-provement'.

${ }^{3}$ Another possible source of corruption - conscious falsification of the text for reasons of religion, ideology, educational or entertainment value, and so on - does not seem to have had a significant impact on the texts of Aristophanes.

${ }^{4}$ Ancient dramatists usually directed their own performances; but we know from the ancient headnotes (hypotheses) to his plays, and from some remarks in the plays themselves (Knights 512-550, Clouds 530-531, Wasps 1018-1029) that Aristophanes often entrusted the direction ( $\delta 1 \delta \alpha \sigma \kappa \alpha \lambda i \alpha)$ of his comedies to the hands of others. He was, indeed, sometimes mocked for doing so (Ameipsias fr. 27 Kassel-Austin; Aristonymos fr. 3

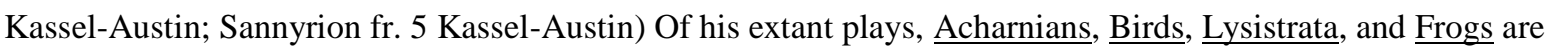
known to have been produced for him by others, and Wasps may have been as well (the evidence of the hypothesis has been questioned, since it seems to be asserting that the same person, Philonides, directed two comedies entered for one and the same competition; see Sommerstein 1983, xv; and 2001, 264); Knights,

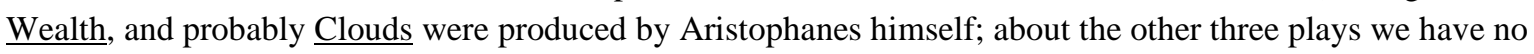
information.

${ }^{5}$ On whom see Holwerda $(1964,1967)$.

${ }^{6}$ Another scholion on the same passage reports a gap $(\delta i \alpha \dot{\lambda} \varepsilon \mu \mu \alpha)$ of anything up to eleven lines. Both these scholia are corrupt; their text, and relationship to each other, are discussed by Holwerda (1967, 261-263). ${ }^{7}$ We do not know which passages he was referring to.

${ }^{8}$ If the substitute text was written at the last minute, he may have been dissatisfied with its quality; comic dramatists sometimes accused each other of overhasty composition (see Acharnians 851; Eupolis fr. 205 KasselAustin), and Aristophanes is known to have felt vulnerable to this accusation (witness his elaborate 'sick note' in Ar. fr. 346 Kassel-Austin)

${ }^{9}$ See Sommerstein $(1996,20-21,162-163)$.

${ }^{10}$ The passages concerned are 1251-1260, 1431a-b, and 1437-1453; it is also possible that the reference to Adeimantos in line 1512 was freshly inserted for the second performance. For discussion, with references, see Sommerstein (1996, 21-23, 268-269, 285-288, 297-298), with updates in Sommerstein (2001, 317-318) (add now Willi 2002, 17-20).

${ }^{11}$ On the revision of Clouds, see Dover (1968, lxxx-xcviii), Kopff (1990), Tarrant (1991), Storey (1993), Henderson (1993), Csapo (1993), Sommerstein (1997), Casanova (2000), and Revermann (2006, 326-332). ${ }^{12}$ At least, the revisions we know of were minor (variant versions of lines 115 and 119); it is of course possible that more extensive changes were made in other scenes.

${ }^{13}$ See Sommerstein (2001, 28-33) following Rogers (1907, vii-xiii), and contesting a suggestion by MacDowell (1995, 324-327) and, for much valuable additional linguistic evidence, Willi (2003).

${ }^{14}$ Another way in which more than one version of a text might go into circulation at an early stage is exemplified by the case of Aristophanes' late play Aiolosikon. Ancient scholars knew of a 'first' and a 'second' Aiolosikon (Choiroboskos, Scholia on Hephaestion p.235.13-14 Consbruch; Prolegomena de Comoedia XXXa Koster = Ar. test. 2a.13 Kassel-Austin), and one fragment (fr. 5 Kassel-Austin) is explicitly cited as from the second. Now Platonios (Diff. Com. 27-38 Perusino = Proleg. I 22-31 Koster) says that Aiolosikon had no choral songs; and yet we possess three fragments (frr. 8-10 Kassel-Austin) that are unquestionably lyric (in three different metres, moreover) and some if not all of which, in any other play, would certainly have been thought to come from choral songs. Wilamowitz $(1921,396 n 2)$ suggested, I believe correctly, that the 'first' and 'second' Aiolosikon were simply two versions of the same script, in one of which the choral songs were written out in
} 
full while in the other they were represented by $\chi$ opoũ , as in the Menander papyri and patchily in our manuscripts of Clouds (at 888/889), Ekklesiazousai, and Wealth: our lyric fragments are derived from the longer version, Platonios' assertion from the shorter.

${ }^{15}$ Most ancient scholars seem to have believed that Aristophanes also had a third son who, like the other two, became a comic dramatist, but they could not agree on who it was: Apollodoros said it was Nikostratos,

Dikaiarchos said it was Philetairos (Arethas on Plato Apology 19c). We have no way of knowing which, if either, of them was right. On the importance of family archives in the early transmission of dramatic texts, see Revermann $(2006,84)$.

${ }^{16}$ Not everyone agreed, at least in Araros' later years; a character in Alexis' Parasitos (Alexis' career began in the 350s) is made to say that he has a very cold well in <the courtyard of> his house 'more frigid than Araros' (Alexis fr. 184 Kassel-Austin)!

${ }^{17}$ Hypothesis III (Chantry) to Wealth; with one of these Araros won first prize at the City Dionysia of 387/6 (IG ii $\left.^{2} 2318.196\right)$.

${ }^{18}$ Suda a 3737.

${ }^{19}$ For western Greek interest in Athenian Old Comedy at this period, see Taplin (1993, 12-20, 30-47). If

Revermann $(2006,254-259)$ is right in his daring suggestion that the present ending of Lysistrata (1295-1321) was added for a production at the Spartan colony of Taras, I would bet on Araros as the producer and 385-375 as the date.

${ }^{20}$ In the Lenaian Victors' List, he is next, but one before Anaxandrides ( $\underline{\mathrm{IG}}$ ii $^{2}$ 2325.140-142) whose first victory was in 376 (Parian Chronicle, FGrH 239 A 70).

${ }^{21}$ See for example Ar. Birds 1288-1289 with Dunbar (1995, 639), and Plato's Apology 26d-e.

${ }^{22}$ I say 'retaining' rather than 'acquiring', since it is clear from the distribution of surviving fragments that many comic texts survived from before Aristophanes' time, mainly from the 430s but including some from the 440s.

In contrast, of the plays of Magnes, who was active ca. 475-455 and whose record of eleven Dionysian victories remained unmatched, there survive only eight attributed fragments; even if these are genuine, texts of Magnes' plays must have been very rare.

${ }^{23}$ [Plutarch], Lives of the Ten Orators $841 \mathrm{f}$.

${ }^{24}$ On these, Page (1934) remains valuable; see too Kovacs (2005, 381-382), also (on Aeschylus' Seven against Thebes) Dawe $(1967,1978)$ and Taplin $(1977,169-191)$, and (on Euripides' Iphigeneia at Aulis) Kovacs (2003).

${ }^{25}$ See Lowe (1962, esp. 34-37).

${ }^{26}$ For example, the single iambic line Wealth 393 consists of six speeches, and in the five lines 392-396, there are sixteen changes of speaker.

${ }^{27}$ Acharnians and Birds both have twenty-two speaking characters (excluding the chorus). The highest figure for any surviving tragedy is eleven (in Euripides' Phoinissai and the pseudo-Euripidean Rhesos).

${ }^{28}$ See MacDowell (1994).

${ }^{29}$ On scholarship in the Hellenistic age generally, see Pfeiffer (1968) and Reynolds and Wilson (1991, 5-18); on the Hellenistic study of Aristophanes, see Henderson (1987, lix-lxviii) and Dunbar (1995, 31-40).

${ }^{30}$ Such as both the plays known to have competed against Acharnians at the Lenaia of 425 -Kratinos' Cheimazomenoi (on which hypothesis I to Acharnians has the note ou) s\%/zontai) and Eupolis' Noumeniai.

${ }^{31}$ For example, Aristophanes' second Peace — which Krates of Mallos, working at the rival library of Pergamon, was able to cite, but which Eratosthenes at Alexandria, a generation or two earlier, had assumed to be totally lost if indeed it had ever existed (hypothesis A2 [Holwerda] to Peace; see Sommerstein (1985, xix-xx), Olson (1998, xlviii-li).

${ }^{32}$ This is in $\underline{\mathrm{IG}} \mathrm{ii}^{2} 2321$, a small fragment of the great Didaskaliai inscription, which gave the full results, so far

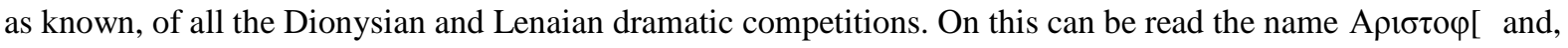

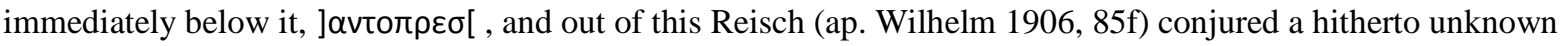

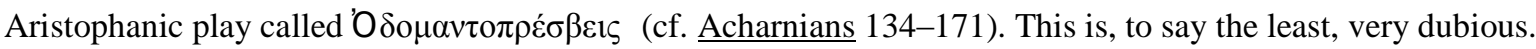
The surviving letters are well to the right of their column, as is evident from the fact that only the last four letters of the next line remain and only the final letter of the following one; so it is by no means guaranteed-indeed, to judge by the sequence in which information is presented in other parts of the inscription, it is very unlikely- 
that the play title in the second line belongs to the poet named in the first (if it is indeed a poet rather than an actor). Nor do we know the date of the production here recorded; so we cannot tell whether the poet (if poet it is) is Aristophanes or the fourth-century dramatist Aristophon.

${ }^{33} \mathrm{~S}$ Wasps $91,103,239,704$, Peace 199, 702, Thesm. 567, Frogs 1356, Wealth 1194. In most of these, he is cited for an explanation of a rare word, but at Frogs 1356 he makes the (fairly obvious) observation that the Mount Ida referred to is in Crete, while at Wealth 1194 he claims (wrongly) that this was the first comic exodos for which torches were brought on stage (as later became the regular convention: cf. Menander, Dyskolos 963964, Misoumenos 459 Sandbach $=989$ Arnott, Samia 731, Sikyonios 418).

${ }^{34}$ Whenever Kallimachos' scholarly work is referred to in the Aristophanic scholia, he appears to be using the comedies as a source of information, whether on bird species (S Birds 302,765, 884, 1181), the dates of dramatic productions (S Clouds 553, Birds 1242), or Athenian festivals (S Thesm. 80).

${ }^{35} \mathrm{His}$ treatise on Old Comedy was clearly very wide-ranging; he is cited over twenty times in the Aristophanic scholia on matters of language (often controverting Lykophron), literary and political history, theatrical practice, and twice on textual issues (see next note).

${ }^{36}$ Two remarks by Eratosthenes on the Aristophanic text survive. On Wasps 1032, and on the identical line Peace 755, the scholia criticise him for failing to perceive that Kóvvns was the name of a hetaira, and on the Peace passage, they add that Eratosthenes proposed or adopted (we cannot tell which) the reading kvvò $\varsigma\langle\dot{\omega} \varsigma\rangle$. Probably the explanation is that he was using a manuscript that read kunhj (as some surviving MSS do in both passages), saw that this was unacceptable, but excusably mistook the nature of the corruption. On Frogs 1263 he criticised $\tau \tilde{\omega} v \psi \varepsilon v \delta \alpha \tau \tau \kappa \kappa \tilde{\omega} v \tau \imath v \alpha \varsigma$ for (he alleged) deliberately corrupting $\tau \tilde{\omega} v \psi \eta \dot{\varphi} \varphi \omega v \lambda \alpha \beta \dot{\omega} v$ to $\tau \dot{\omega} \psi \eta \dot{\eta} \varphi \omega$

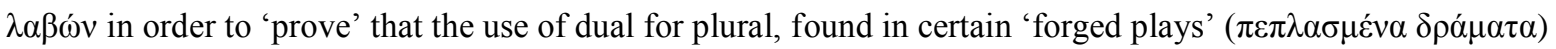
whose authors did not understand what the dual number meant, was not a solecism but a genuine phenomenon of Attic!

${ }^{37}$ Three of his textual decisions are explicitly mentioned in the surviving scholia. In the neighbourhood of

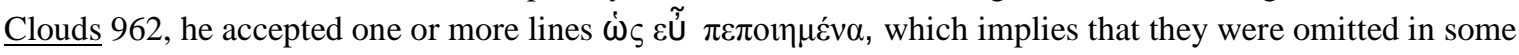
manuscripts known to him; probably this refers just to line 962 itself, which is not essential to the sense of the passage and could have been lost by homoeoteleuton. In Birds 1343, where some manuscripts marked a one-line lacuna, he proposed a supplement $(\pi \lambda \eta \dot{\eta} \omega \mu \alpha)$. In Thesm. 162 he either proposed or adopted the reading

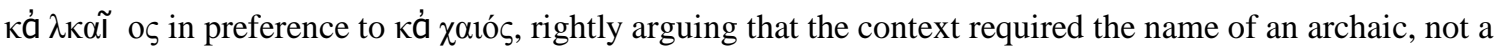
near-contemporary, poet. In all three cases, the medieval tradition conforms with his view (as do the two papyri that include the Clouds passage).

${ }^{38}$ The only (but sufficient) reference to such signs inserted by Ar. Byz. is at Frogs 153 where the scholia state that he placed the signs antisigma and sigma (to indicate a doublet). The sign chi-which is frequently mentioned in the scholia (e.g., on Clouds 518, 562, 768, 817-819, 965, and 1176) as a marker of almost any matter of critical or exegetical interest-is never associated with the name of Ar. Byz. (only with that of Aristarchos, and then only once, on Birds 76) and presupposes the existence of a commentary (see below) to which the reader may refer for further information.

${ }^{39} \mathrm{He}$ is cited on a point of accentuation by $\Sigma$ Clouds 550 .

${ }^{40}$ In Dion.Hal. de comp. verb. 23, 26 he is the archetypal colometrician. However, colometrised lyrics were not entirely unknown before his time (the third-century Lille papyrus of Stesichoros is an example), and the colometry in the medieval MSS of Aristophanes is stated (in endnotes to Clouds and Peace) to be based on that of Heliodoros (first century CE).

${ }^{41}$ The headings of many of these hypotheses contain an attribution to him; in the case of the prose hypotheses, this can at most refer to their origin, not their present state, and in the case of the verse ones (which are entirely lacking in poetic quality and informational value alike), it is certainly false.

${ }^{42}$ See note 37 above.

${ }^{43}$ Euphronios' commentary is the earliest attested on any poet; see Wilson $(2007 \mathrm{a}, 41)$. Pfeiffer $(1968,160)$ and Trojahn (2002, 125-6) actually place him before Ar. Byz.; but as Henderson (1987, lxii n.18) pointed out, Euphronios was commentating on a text already equipped with critical signs (see $S$ Wasps 696).

${ }^{44}$ See S Wasps 772, Thesm. 917 (unfortunately defective; the scholiast seems to be accusing Kallistratos of misrepresenting the views of his teacher), and Frogs 270, 567. 
${ }^{45}$ Readings: S Frogs 191, 970 (where Aristarchos seems to have suppressed all mention of the two readings that dominated the later tradition). Accentuation: S Knights 487. Speaker assignments: S Frogs 1149. Authenticity: S Frogs 1437 (regarding 1437-1441 and 1452-1453 as spurious). On Aristarchos' work on Aristophanes, see now Muzzolon (2005).

${ }^{46}$ Including Apollonios (son of Chairis), Asklepiades, Demetrios Ixion, and Timachidas (some of these may not have written full-scale commentaries, and some may have worked only, or almost only, on Frogs, doubtless because of its importance for the study of tragedy); another important figure was Ammonios, a pupil of

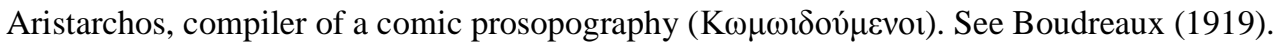

${ }^{47}$ See Boudreaux (1919, 91-137).

${ }^{48}$ Of his two known significant textual comments on Aristophanes, that on Frogs 775 is a sensible defence of $\lambda v \gamma 1 \sigma \mu \tilde{\omega} v$ against the banalising variant $\lambda \sigma \gamma 1 \sigma \mu \tilde{\omega} v$; on Thesm. 162, on the other hand, Didymos makes an utterly hare-brained attempt to argue that кá $\lambda \kappa \alpha \tilde{I}$ os must be wrong (or else must refer to a contemporary musician) because the poetry of Alkaios was not widely known in Aristophanes' time!

${ }^{49}$ Symmachos appears to have been active in the late first or early second century CE; see Boudreaux (1919, 144-170). He is mentioned as a source in endnotes in some MSS of Clouds, Peace, and Birds; the first two of these notes also add the name of an apparently later commentator, Phaeinos. To judge by the comments to which Symmachos' name is attached in the scholia, he was remarkably well informed and judicious, and not afraid to admit that he found the text unintelligible. In at least two passages (Clouds 819, Birds 885), he was using a text that contained a significant error from which the medieval tradition is free.

${ }^{50}$ Suda d $872, \mathrm{i} 399$. He is reported to have written more than 3,500 books (i.e., papyrus rolls); if we generously allow him a working life of fifty years, he must therefore have completed one book every five days, inclusive of all rest periods, illnesses, and other interruptions.

${ }^{51}$ Athenaios $4.139 \mathrm{c}$, citing Demetrios of Trozen.

${ }^{52}$ S. R. West (1970, 296); see also Harris (1989). Harding (2006) largely vindicates the originality of Didymos' work, but does not seriously upset earlier judgements of its quality.

${ }^{53}$ This is the conventional term for fragments of ink-written manuscripts surviving from antiquity and discovered by excavation in modern times, mostly in Egypt but sometimes elsewhere (e.g., Herculaneum, Derveni); it is not entirely accurate, since many of them, especially the later ones, are written not on papyrus but on parchment.

${ }^{54}$ The data analysed below are based on the records in the Mertens-Pack ${ }^{3}$ database (http://promethee.philo.ulg.ac.be/cedopal/index.htm), consulted on 2 August 2006. I have counted all papyri that are attributed by the database itself (not by others whose views it reports) to Old Comedy or to an individual Old Comic author, including those which contain only scholia or a hypothesis; where it is uncertain whether a fragment should be attributed to a named author or should be regarded as anonymous, I have been guided by the editorial decisions of Kassel and Austin (1983- ). Where the database reports divergent views on the date of a papyrus, I have adopted the unbracketed alternative; where a dating straddles a century boundary, I have assigned the papyrus to the century containing the greater part of the dating window or, failing this, to the earlier century (thus a papyrus dated 'II ex.-III' is treated as third century, but one dated 'II ex.-III in.' is treated as second century).

${ }^{55}$ Horace Satires 1.4.1; cf. Velleius Paterculus 1.16.3, Persius 1.123-4, Quintilian 10.1.66, [Dion. Hal.] Art of Rhetoric 8.11.

${ }^{56}$ These cover eight of the eleven plays, none being represented more than three times (Knights, Wealth).

${ }^{57}$ Though often not attributable to a specific play. This figure is almost certainly understated, since Aristophanes was doubtless the author of a high proportion of those fragments, which, for lack of evidence, we are obliged to label 'anonymous'.

${ }^{58}$ No papyrus fragment, of any date, is known to survive from any copy of the text of a work of any Old Comic

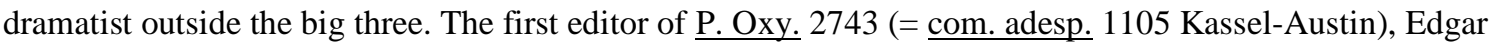
Lobel, tentatively attributed it to the Lemnomeda of Strattis, because line 7 of the papyrus appears to be identical with a line elsewhere quoted from that play (Strattis fr. 24 Kassel-Austin); but he himself pointed out that 'as the quotation is a proverb, the identification is less than certain', and the coincidence has not discouraged later scholars from attributing the papyrus to Eupolis or Kratinos. 
${ }^{59}$ All eleven are represented, Clouds appearing most frequently (six papyri), followed by Wealth and, surprisingly, Peace (five each).

${ }^{60}$ P. Oxy. 1403 (= Aristophanes fr. 594 Kassel-Austin), a tiny scrap (containing not one intelligible word), which is attributed to Aristophanes solely because it is in the same hand as another papyrus (P. Oxy. 1374) containing parts of some 150 lines of Wasps.

${ }^{61}$ This is the famous Cairo codex, of about $400 \mathrm{CE}$, in which is preserved a substantial part of Eupolis' Demes (Eupolis fr. 99 Kassel-Austin), together with parts of several plays of Menander.

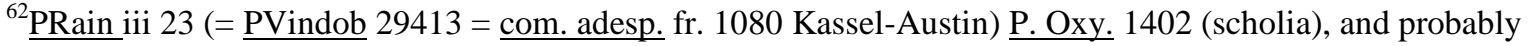
PColumbia inv. 430, whose explicit reference to the audience, twice in successive lines, makes an Old Comic origin very likely (see Barrenechea 2006).

${ }^{63}$ Reynolds and Wilson (1991, 35).

${ }^{64}$ Symposiaka $712 \mathrm{a}$.

${ }^{65}$ See Dover (1968, cxv), who implicitly identifies this commentary as that of Phaeinos (see note 49 above) and argues from a combination of various kinds of evidence that 'the majority of the ancient scholia assumed their present form' in the late third or early fourth century.

${ }^{66}$ Evidence for the status of Aristophanes as a school author goes back at least to the first century; see Trojahn (2002, 135-149). The increasing fetishization of 'pure' Attic Greek benefited Aristophanes at the expense of Menander, whose language had some post-classical features of vocabulary and grammar and is severely criticized by Atticistic grammarians of the imperial period.

${ }^{67}$ On scholia and their origins see Dickey (2007, 11-14 [in general] and 28-31 [on Aristophanes]).

${ }^{68}$ We have part of a fifth-century commentary on Clouds in PRain iii 20 (PVindob G29423), and part of one on Peace in PRain i 34 (PVindob G29780 + 29833C). For a full presentation and discussion of the papyrus commentaries and scholia on Aristophanes, see Trojahn (2002) and Bastianini et al. (2006) with Montana (2005).

${ }^{69} \mathrm{We}$ may consider, as a sample, the thirteen papyri of the extant plays (P. Oxy. 4509-4521) that were published together in P. Oxy. lxvi (1999). These contain, after allowing for one case of overlap, part at least of 427 lines from seven different plays. They offer (or manifestly imply) good readings, unknown to the earlier medieval tradition, at Acharnians 298*, 323*, 325*, 541*; Wasps 1085*, 1102; and Birds 1672* (* denotes confirmation of a modern, or late medieval, conjecture, or of the reading of a secondary source); in Birds 1670, P. Oxy. 4516 confirms a reading found only in one of the main medieval manuscripts; at Wealth 958/959, P. Oxy. 4521

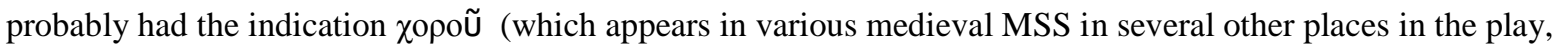
but - until Triklinios - not here), and either before or after Wealth 968, it had an extra line whose existence had never previously been suspected. These thirteen papyri, then, give us altogether ten significant new pieces of information about the Aristophanic text.

${ }^{70}$ On whom see Wilson $(1983,89-119)$.

${ }^{71}$ In one passage, Wealth 50, there appear to be as many as four such readings--though one of them (probably, as it happens, the correct one) has survived only as a marginal variant.

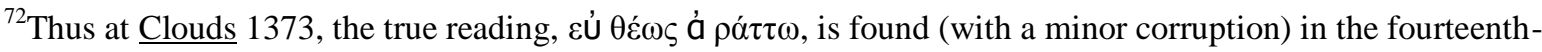
century MS Vb3 (and the unmetrical variant $\varepsilon \cup ̉$ $\theta \dot{u} \varsigma$ á pó $\tau \tau \omega$ in another, Vs1); it can hardly be an emendation, since the medieval vulgate, $\varepsilon \dot{u} \theta \dot{u} \varsigma \dot{\varepsilon} \xi \alpha \rho \alpha ́ \tau \tau \omega$, would not have been thought unsatisfactory (it was generally, though not universally, accepted by modern scholars until the publication of PStrasb inv. 621).

${ }^{73}$ More than three-quarters of which, however, belong to the fifteenth century or later. The statement of Sommerstein $(1980,17)$, that 'the total number of Aristophanic manuscripts...is not far short of three hundred', includes the many MSS that do not contain, and never did contain, the full text of any play, but only extracts, scholia, Hypotheses, or prolegomena.

${ }^{74}$ These four plays, in the order given, are the first four in R.

${ }^{75}$ Three should be added to those listed by White (1906) and by Dover (1968, c-ci n2): Vaticanus gr. 2336 (Vv19) (Koster 1974, lxxxiii); Holkhamensis 89 (L2) (ib. lxxxv); and Athous, Iviron 4269 (Ma6) (Tzannetatos and Soulogiannis 1965/6). 
${ }^{76}$ There are eighteen manuscripts of Birds, sixteen of Acharnians, twelve of Wasps, ten of Peace (but only R, V, and a copy of $\mathrm{V}$ contain lines 948-1011), eight of Lysistrata (but nearly a quarter of the play is preserved only in $R$ and a copy of R), seven of Ekklesiazousai, and just two ( $R$ and a copy of $R$ ) of Thesmophoriazousai.

${ }^{77}$ See Diller $(1974$, 522-523).

${ }^{78}$ Called F by Sommerstein (1987), and Laur. by Dunbar (1995) and Wilson (2007b).

${ }^{79}$ See Dunbar (1995, 20-21).

${ }^{80}$ See Wilson $(1977,237)$.

${ }^{81}$ Called M4 by White (1906).

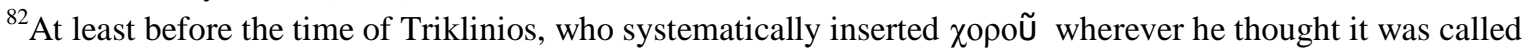
for. See on this subject Koster (1957, 117-135, esp. 121-124).

${ }^{83}$ The alphanumerical sigla used for most Aristophanic manuscripts are based on the ingenious system devised by White (1906) under which, in general, one or two alphabetic characters denote the city in which the manuscript is located (or, in the case of manuscripts in the Vatican, the collection to which it belongs) and are followed by a numerical distinguisher. Thus Md1 means the first Madrid MS in White's listing.

${ }^{84}$ Containing Wealth 1-528, all of Clouds, and Frogs 1-959; the rest of the triad, and part of Knights, were added in the fifteenth century.

${ }^{85}$ See Wilson $(2007 \mathrm{c}, 6-7)$.

${ }^{86}$ On whom see Wilson (1983, 190-196) and Massa Positano et al. (1960, xix-cxxviii).

${ }^{87}$ See Dover (1968, cxxi).

${ }^{88}$ On whom see Wilson (1983, 249-256).

${ }^{89}$ On the witnesses to the state of the text in early Palaiologan times in the triadic plays, see Dover (1968 cxxicxxv); Eberline (1980, 146-160); Dover (1988); Dover (1993) 82-94.

${ }^{90}$ All these manuscripts are of the fourteenth (or possibly, in some cases, late thirteenth) century.

${ }^{91} \mathrm{~A}$ leaf of A containing Ekklesiazousai 283-444, which had been lost from the manuscript not long after the time of Brunck's edition (1783), has been rediscovered and collated by Förstel and Rashed (2003).

${ }^{92} \mathrm{E}$ has lost the pages containing Birds 222-601, but its copy, Ambrosianus L41 sup. (M9), which was made before $\mathrm{E}$ was damaged, can serve as a reliable substitute.

${ }^{93}$ See Olson (1998, lxii-lxv) on how it came about that $\Gamma$ preserves only about half of Peace (and that in a muddled order).

${ }^{94}$ Called J by MacDowell (1971).

${ }^{95}$ Called P by Platnauer (1964), Dunbar (1995), and Olson (1998, 2002), and by Wilson (2007b) in Peace and Birds.

${ }^{96} \mathrm{C}$ has often been regarded as a copy of $\mathrm{Vp} 2$ in some plays and of $\mathrm{Vp} 3$ in others, and thus of no independent value; but see Olson (1998) lvi-lvii, lxx, (2002) lxxxvii-lxxxviii.

${ }^{97}$ So labelled by Ussher (1973), Sommerstein (1998), and Wilson (2007b); Vetta (1989) retained White's siglum Pe1.

${ }^{98}$ That Mu1 (Monacensis 137) is a copy of $\Lambda$ has been shown by Vetta (1989, lxviii-lxix).

${ }^{99}$ See M. L. West (1973, 14-15, 37-47) and (on correction in the Byzantine triad of Aristophanes) Dover (1988, 234-240).

${ }^{100}$ For example, $\mathrm{V}$ and $\mathrm{E}$ are closely related in Knights and in the first 385 lines of Birds (taking M9 to represent E in $222-385$, see note 89 above), but not elsewhere.

${ }^{101}$ This has been done in exemplary fashion for Ekklesiazousai by Vetta (1989, 1xv-lxix), for Birds by Dunbar (1995), and for Peace and Acharnians by Olson $(1998,2002)$.

${ }^{102}$ The few comments ascribed to them in later scholia may derive either from their oral teaching or from marginalia in their copies of the plays; see Eberline $(1980,146)$.

${ }^{103}$ See Wilson (1983, 238, 244-247).

${ }^{104}$ See, for example, Dover (1968, cxvii-cxix) (on Clouds); Eberline (1980, 86-88) is uncertain, and in any case concludes that 'Thomas seems to have cared little for textual criticism in the modern sense'.

${ }^{105}$ See Wilson $(1983,248)$, who regards 'the use of such a term [as recension as being] the result of loose thinking'.

${ }^{106}$ See Koster (1957), Eberline (1980, 49-77, 88-114), and Dover (1993, 81-83). 
${ }^{107}$ See Wilson (1962).

${ }^{108}$ Though he understands them considerably better in his later work than in his earlier (Eberline 1980, 76-77).

${ }^{109}$ For his edition of Clouds (1968), Dover used information about the readings of sixty-seven manuscripts. Eleven of these are certainly or probably too early to have been able to make use of Triklinios' work; of the remaining fifty-six, no fewer than thirty-three 'show (in varying degrees) Tri[k]linian "trade-marks" in lyrics and eupolideans' (Dover 1968, cxvi-cxvii), not counting those into which Triklinian readings have been imported as corrections or variants.

${ }^{110}$ See Sommerstein $(1998,38)$.

${ }^{111}$ When B's exemplar was copied from $\Gamma, \Gamma$ still contained Lysistrata 1035-1097 and 1237-end, which it afterwards lost.

${ }^{112}$ Some of these also figure in the Aldine edition, and it is possible that these are Triklinian emendations that for some reason did not get into $\mathrm{L}$.

${ }^{113}$ On Kallistos' life and work, see Cammelli (1942) and Wilson (1992, 116-118). For another exemplification of his critical ability, see the discussions of his work on Lysias by Donadi (1976, 240-250),Sosower (1987, 62), and Carey (2007, xviii).

${ }^{114}$ This occurs about eleven times in Wasps alone; on nine of these occasions, the Suda (sometimes alone, sometimes in agreement with other sources) has the true reading. The Aristophanic testimonia were collected by Kraus (1931), since supplemented by Kassel $(1977,1978)$.

${ }^{115}$ On whom see Lowry (1979) and Sicherl (1997).

${ }^{116}$ This manuscript was identified as Musurus' copy text by Sicherl (1979; revised in Sicherl 1997, 114-154); but see now also Olson (1998, lx-lxii). It was probably copied (by Zacharias Kallierges) at Musurus' request in 1497, expressly for use in preparing the edition (Sicherl 1997, 131).

${ }^{117} \mathrm{E}$ has on its first page the inscription 'De miser Marco Musuro'.

${ }^{118}$ See Olson (1998, lxi-lxii) (contra Sicherl 1997, 138-145). This manuscript probably also contained (as Vp2, $\mathrm{H}$, and $\mathrm{C}$ do) the greater part of Lysistrata; Aldus could have printed this had he wished to, but declined to do so because the gaps were too great, amounting (he says) to nearly half the play (in fact, as we now know, to just over a quarter of it).

${ }^{119}$ See Sicherl $(1997,146)$. In the first 1135 lines of the play (where $\Gamma$, and at first also A, are available for comparison), the Aldine dozens of times agrees with $\Lambda$ alone in manifest error. Its text is unlikely, however, to

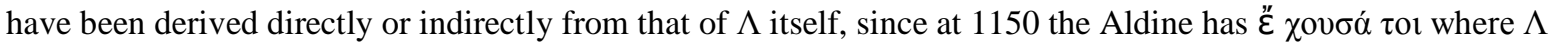

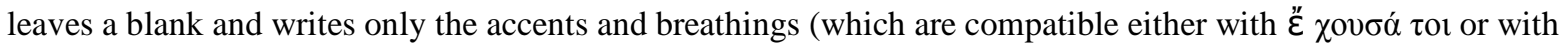
R's है $\chi \omega \delta \varepsilon \dot{\tau} \tau 01)$. See now Regtuit (2007, 72-73).

${ }^{120}$ As was the fate of many conjectures on Thesmophoriazousai from the sixteenth, seventeenth, and even early eighteenth centuries, until they were rediscovered in recent years by Schreiber (1975) and Austin (1987).

Finglass $(2009,201-2)$ publishes some fifty previously unknown conjectures by L.C. Valckenaer (1715-1785) on all Aristophanes' plays. 